\title{
编者按 嫦娥五号探测器专题I
}

\section{前言——嫦娥五号探测器专题}

嫦娥五号任务作为我国复杂度最高、技术跨度最大的航天系统工程, 首次实现了我国地外天体采样返回. 嫦 娥五号探测器由轨道器、返回器、着陆器和上升器组成, 包括结构、机构、测控数传、天线、数管、供配电、 热控、采样封装、工程参数测量、GNC、推进、回收、对接机构与样品转移、分离机构和有效载荷共 15 个分系 统. 2020年11月24日, 探测器在海南文昌成功发射; 12月1日, 着陆上升组合体在月球正面预定区域着陆, 在月面工 作了 2 天, 分别通过钻取和表取两种采样方式获得了月球样品, 并完成了就位科学探测; 12 月 3 日, 上升器以着陆器 为平台, 零窗口起飞上升进入预定环月轨道; 12月6日, 轨返组合体与上升器完成了月球轨道交会对接与样品转 移; 12月13日, 轨返组合体完成月地转移入射; 12 月17日, 返回器携带月球样品在内蒙古四子王旗地区着陆, 任务 取得了圆满成功.

嫦娥五号探测器研制过程中突破了一系列关键技术，包括月面无人自动采样返回探测器系统设计、月面自 动采样封装、月面起飞上升、无人月球轨道交会对接和样品转移、月地转移入射、携带月球样品高速再入返回 地球、复杂探测器装配集成与测试(AIT)以及月面无人自动采样返回地面综合试验等. 本专题是研制团队部分研 究成果与经验总结.

嫦娥五号探测器在月面工作期间，不仅获取了表取和钻取两种月球样品，同时有效载荷开展了探测工作，建 立了月球样品现场分析与地面实验室研究数据的关联关系, 为相关月球科学研究提供有力支撑. 目前月球样品已 按计划进行存储、制备和处理, 国内多家科研单位正申请开展月壤结构、物理特性、物质组成等相关科学研究, 将为深化人类对月球成因和太阳系演化历史的科学认知做出贡献.

杨孟飞, 黄昊 中国空间技术研究院, 北京 100094

引用格式: 杨孟飞, 黄吴. 前言—嫦娥五号探测器专题. 中国科学: 技术科学, 2021, 51: 737

Yang M F, Huang H. Preface — Special Topic on Chang'e-5 Probe (in Chinese). Sci Sin Tech, 2021, 51: 737, doi: 10.1360/SST-2021-0275 